\title{
Customers Awareness and Purchase Behaviour towards Organic Food
}

Lily Nurainul Ashikin Ishak, Zatul Iffah Mohd Fuza, Mohd Amar Ridham Othman, Siti Aisah Abas

To Link this Article: http://dx.doi.org/10.6007/IJARBSS/v11-i16/11223

DOI:10.6007/IJARBSS/v11-i16/11223

Received: 02 July 2021, Revised: 22 August 2021, Accepted: 29 August 2021

Published Online: 29 September 2021

In-Text Citation: (Ishak et al., 2021)

To Cite this Article: Ishak, L. N. A., Fuza, Z. I. M., Othman, M. A. R., \& Abas, S. A. (2021). Customers Awareness and Purchase Behaviour towards Organic Food. International Journal of Academic Research in Business and Social Sciences, 11(16), 130-139.

Copyright: (C) 2021 The Author(s)

Published by Human Resource Management Academic Research Society (www.hrmars.com) This article is published under the Creative Commons Attribution (CC BY 4.0) license. Anyone may reproduce, distribute, translate and create derivative works of this article (for both commercial and non-commercial purposes), subject to full attribution to the original publication and authors. The full terms of this license may be seen at: http://creativecommons.org/licences/by/4.0/legalcode

Special Issue Title: Contemporary Issues in Tourism and Hospitality industry, 2021, Pg. 130 - 139

Full Terms \& Conditions of access and use can be found at http://hrmars.com/index.php/pages/detail/publication-ethics 


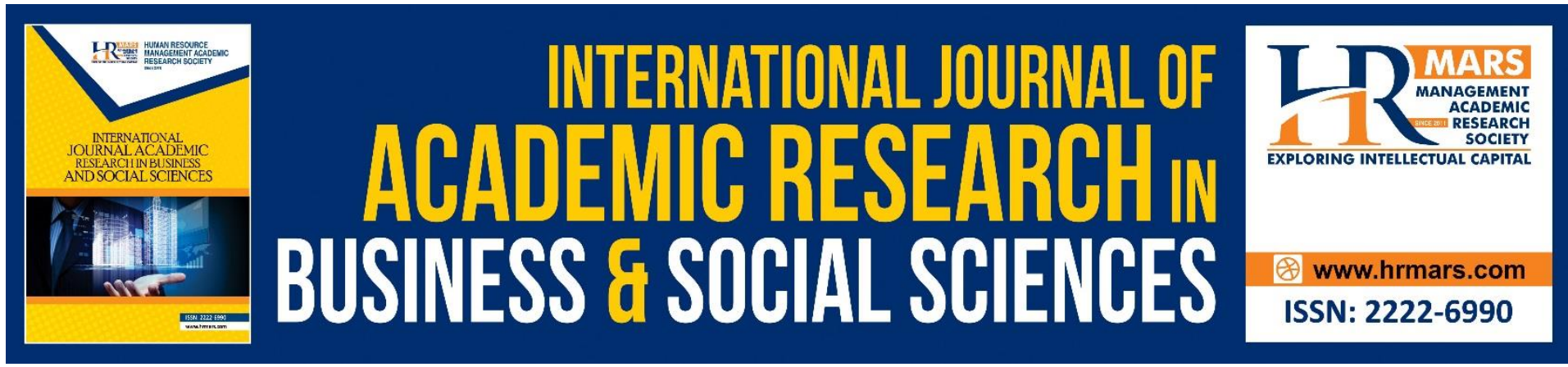

\title{
Customers Awareness and Purchase Behaviour towards Organic Food
}

\author{
Lily Nurainul Ashikin Ishak ${ }^{1}$, Zatul Iffah Mohd Fuza ${ }^{1}$, Mohd Amar \\ Ridham Othman², Siti Aisah Abas $^{3}$ \\ ${ }^{1}$ Universiti Teknologi MARA Cawangan Terengganu, Kampus Dungun, Malaysia, ${ }^{2}$ Universiti \\ Malaysia Terengganu, Malaysia, ${ }^{3}$ International Islamic University Malaysia, Pagoh Campus \\ Email: zatul710@uitm.edu.my
}

\begin{abstract}
Organic food may be a safer and healthier alternative to conventional food, particularly in COVID19 pandemic conditions where stay-at-home arrangements may encourage the willingness to plan, select, and prepare more nutritious foods in order to strengthen the immune system or maintain fitness. However, organic food consumption is relatively still low even in countries with a well-established organic food market. A similar pattern is happening in Malaysia, where there is an increase in organic farms throughout the years, yet the consumption level is very disappointing. Therefore, this study is conducted to explore customers awareness and purchase behaviour among Malaysian customers. A questionnaire survey is used to collect data from the members of consumer association. Data from 403 respondents are collected, analysed and discussed in the study. This study found out that most Malaysian food buyers are aware of organic food and buy organic food. Most food buyers understand organic food as natural food. The key reason for buying organic food is health-related. In comparison, the main reason for not buying organic food is the price itself. This study will contribute to the body of knowledge regarding Malaysian organic food consumers. The findings of this study can be utilised to understand the Malaysian organic food market better and, simultaneously, lead to the development of the organic food market and the organic food consumption level in Malaysia.
\end{abstract}

Keywords: Organic Food, Customer Awareness, Purchase Behaviour, Food Preference, Food Consumption

\section{Introduction}

Organic food needs to conform with certified organic standards for cultivation, handling, processing, and marketing, with the use of artificial fertilisers, pesticides, and genetic alteration all being prohibited (Brantsæter et al., 2017). One important reason for the increased interest is the realisation that organic food is less harmful to the environment than conventionally produced food (Brantsæter et al., 2017). The organic food industry has reported growth in these past few years. They have become a hot topic in a rapidly expanding food business, as consumers seek alternatives to the current traditional items (Connor \& Douglas, 2001). Customers often consider organic food a safer and healthier choice than 
conventional food (Wier et al., 2008), especially in COVID19 pandemic situations where stayat-home arrangements may expand the willingness to plan, select, and prepare more nutritious foods (De Backer et al., 2020).

According to the Malaysian Department of Agriculture (2001), there were 27 organic farmers in 2001, with a total area of 131 hectares. Furthermore, organic products are limited to vegetables and fruit, particularly in East Malaysia. However, the Department of Agriculture reported 89 organic farms occupying 1634 hectares of land in 2013, with 49 farmers holding a valid certification. This expansion may have resulted in increased organic food consumption and positive attitudes about organic foods among consumers (Ahmad \& Juhdi, 2010). Malaysians are becoming more aware of the health benefits of eating organic foods, which are more nutritious and environmentally friendly, according to Tiraieyari et al. (2014). Despite the organic food industry's expansion, organic food consumption is still shallow (Narine et al., 2015; Zagata, 2012). Conventional food continues to account for the majority of global food consumption (Saleki et al., 2019). Even in nations where the organic food market is very well established, such as Austria, Switzerland, and Denmark, organic food consumption is barely over $5 \%$ of overall food consumption (Willer et al., 2016). Additionally, according to Rahman and Noor (2016), local organic food consumption in Asia is less than $1 \%$ of total food consumption. In Malaysia, even though the number of hectares under organic cultivation increased by 1634 in 2013, the local organic food business is relatively modest, with most organic products marketed domestically and some exported to Singapore (Somasundram et al., 2016).

Organic foods are well known for the benefits they have. How food is grown or raised can significantly impact mental and emotional health and the environment (Robinson et al., 2020). In addition, Robinson et al. (2020) mentioned the various benefits of organic foods, such as they commonly have more valuable nutrients, like cell reinforcements, than conventional foods. Other than that, individuals with sensitivities to food sources, synthetic substances, or additives frequently discover their indicators decrease or disappear when they eat just organic food varieties (Robinson et al., 2020). Moreover, certain plants grown organically contain higher levels of antioxidants, have a better flavour than conventionally grown strawberries and have a better taste than conventionally grown apples (Gore, 2008). Nevertheless, with all these benefits, organic food still cannot compete with conventional food. There is a big gap in national consumption between organic food and conventional food. Therefore, this study will attempt to answer are Malaysian food buyers aware of organic food? Who are the buyers of organic food in Malaysia? Why did they buy organic food? And why did not they buy organic food? Hence, this study aims to explore customer awareness and purchase behaviour towards organic food in Malaysia.

\section{Literature Review}

\section{Organic Foods and Customer Awareness}

Organic food is defined by Meza and Park (2016) in Septianto and Kemper (2021) as items produced and handled without the use of dangerous synthetic inputs or additives, irradiation, or genetically engineered organisms. Compared with conventional food, organic food is primarily considered to have a somewhat higher dietary benefit because organic food is produced more regularly, not including harmful pesticides or synthetic compounds (Pino et al., 2012). Fresh organic foods are the most common, although they can also be produced (Connor \& Douglas, 2001). There are two types of manufactured organic foods: 1 ) products that contain $95 \%$ to $100 \%$ certified organic ingredients are the only ones that can be labelled 
"organic," such as organic potatoes, and 2) products that contain at least 70\% certified organic ingredients are labelled "made with organic ingredients" (Connor \& Douglas, 2001). However, there is a lot of confusion surrounding the phrase "organic" (Chryssochoidis, 2000). While many customers are familiar with the term and its key features - namely, that it is chemicalfree - the majority are unfamiliar with organic agricultural ideas and methods (Hill \& Lynchehaun, 2002). Furthermore, factors such as market improvement, the use of other emphatically linked food phrases (e.g., cage-free and natural), and the item class (e.g., farmed salmon) can all contribute to buyer confusion (Aarset et al., 2004).

Baker et al., (2004) portrayed the organic food market as promising and foreseeing to develop firmly. In 2002, the global market for organic food was estimated to be worth $\$ 20$ billion (Fitzpatrick, 2002). Deals in the United States grew from $£ 100$ million in 1994 to $£ 605$ million in 2000. (Hughner et al., 2007). Customers in the United Kingdom spent $30 \%$ more on food and drink in 2005 than they did in 2004, totalling over $£ 1.5$ billion (Murphy, 2008). According to the estimates, organic food sales are expected to grow at a rate of $20 \%$ each year across Europe. The developing interest of customers has driven the improvement of the organic industry where these retailers have assisted development, advancing items, expanding range, and helping ranchers to change over (Ozguven, 2012). Customers see organic food items as healthier than conventional food products because of the low degrees of pesticide and medication buildups (Wier et al., 2008). They also see it as anything but a safer choice since they think consuming it diminishes their exposure to diseases related to pesticide deposits. As indicated by writing, these well-being concerns are tended to by organic cultivating and the work of more secure food handling techniques (Eyinade et al., 2021). The principal reasons that keep customers from purchasing organic food are; excessive cost, absence of accessibility, fulfilment with traditional food, lack of trust, the restricted decision and absence of saw esteem (Makatouni, 2002).

Organic food is commonly associated with an elective lifestyle that includes dynamic environmentalism, vegetarianism, and the use of elective medication (Cicia et al., 2002). According to Hughner et al. (2007), outcomes from demographic profiling research are sometimes contradictory. However, there are certain consistent patterns that have emerged across studies. Organic food customers, on average, are female (Food Marketing Institute, 2001), have children (Thompson \& Kidwell, 1998), and are more informed (Cicia et al., 2002).

\section{Customer Purchase Behaviour}

According to Chinnici et al. (2002), there are four distinct groups of consumers. Each of them shows a specific trend of organic crop consumption. The "pioneer" group is defined by their infrequent use of organic produce, which is mainly motivated by curiosity. This demographic could be persuaded by effective marketing policies to increase their consumption of organic produce. Individuals in the "pragmatist" group are more concerned with pricing, to the point where it is a substantial stumbling block for them when making purchasing decisions. The third, which is described as "health-conscious," is clearly the most well-established. Consumers in this category have been purchasing organic produce from specialised sales outlets for at least two years, preferring fresh veggies over conventional products because they believe they are healthier. Furthermore, these customers are willing to pay 20-30\% more for organic fruit, which can be explained by the group's higher average family income. The final category is the "nostalgic" group, which consists solely of older people who identify organic vegetable intake with the authenticity and flavours of the past. 
Another study done by Fotopoulos and Krystallis (2002) has reported three consumer groups in the Greece market: the unaware, the aware non-buyers, and the buyers of organic food. The study found an additional four clusters in the buyers of the organic food group: the explorer, the greens, the motivated, and the price sensitives. The explorer cluster has an average overall reasonable opinion on organic food. Their organic purchase motivations are improved health and environmental friendliness, and their involvement in the shopping process is minimal. On the other hand, the greens cluster comprises "environmentally conscientious," well educated, young to moderately aged greens buyers. They show the most elevated ecological cognisance, which is their sole organic buying intention. Next, the motivated cluster is formed by the most motivated, extremely confident in the organic thought, young to moderately aged buyers, or those who are essentially"spurred". They display the most elevated of all groups for well-being and environmentally consciousness, the most significant exploratory organic buying conduct and the most negligible value affectability. They have a tremendous general assessment of the organic items (regarding their strength, remaining and added substance-free characteristics, supplements, worth, and kids' eating regimen appropriateness).

In addition, their decision of predominant well-being and ecological compassion is their significant buying reason. Moreover, they are the most included of all in the organic buying measure. The price sensitives are the last cluster, with the second-highest health and quality consciousness and heightened price sensitivity. Baker et al. (2004) discovered that while there were similarities between the two countries (the United Kingdom and Germany) in terms of values related to health, well-being, and enjoyment of life, the item credits sought to achieve these qualities were distinct (the United Kingdom - strength and not genetically altered; Germany - taste and quality). A significantly more marked contrast between the groups was found in the nonattendance among the U.K. gathering of any association between organic food and the environment. Indeed, even the genetic alteration of produce was connected to wellbeing, instead of the environment.

\section{Methodology}

This study implements an explanatory research design to determine the characteristics of data gathered regarding the customer awareness and purchase behaviour for organic food among Malaysians. For that reason, the population of this study is all food buyers in Malaysia. According to the Department of Statistics Malaysia (2021), the estimated population in Malaysia is 32,657 million in the year 2020. Among this population, there are 28,193 million people aged 20-64 years old. This study considered the group of age as the group that has purchasing power or food buyers. A sample size of 385 is chosen for this study using standard measurement with a 95\% confidence level and a 0.05\% margin of error. However, 450 questionnaires are distributed throughout online social media platforms through members of consumer associations to ensure the sample size is achieved. The response rate is $89.5 \%$, with a total of 403 respondents. The questionnaire consists of three sections. Section 1 is aiming to collect demographic data of the respondents. Section 2 and Section 3 consists of close-ended questions related to item organic food awareness and purchase behaviour. All data had been analysed using IBM SPSS software and interpreted. 


\section{Result and Discussion \\ Customers Organic Food Awareness}

Organic food is familiar to more than half of the respondents in this study. Organic food is familiar to $54.1 \%$ of the respondents. Whereas, there is $26.8 \%$ of the respondents are unfamiliar with organic food. Some of the respondents are not sure whether they are familiar with organic food or not (19.1\%). Other than that, most of the respondents understand organic food as natural food (36.5\%). This result conforms with a previous finding by Chan (2001) that stated customers often use terms like "natural," "local," "fresh," and "pure" to refer to organic food. Furthermore, 25.3\% of the respondents aware that organic food is not containing any additional chemicals. As mentioned in Nguyen and Truong (2021), a couple of studies upheld that the typical understanding of food buyers on organic produces is that organic produces are free from pesticides, artificial fertiliser, and residue (Huang, 1996; Jolly et al., 1989). In addition, $12.9 \%$ of the respondents think that organic food is healthy food, while $8.9 \%$ believe organic food is eco-friendly. However, a small number of respondents are not sure what to think about organic food (2.5\%).

On top of that, sources of information such as the media, flyers, newspapers, and family members are frequently used to disseminate information about organic food (Nguyen \& Truong, 2021). For that reason, most of the respondents are getting information on organic food through online media sources (39.5\%). Additionally, some respondents receive information on organic food through other media platforms like television, magazines, and newspapers (10.7\%). Other than that, 39\% of the respondents obtain information on organic food from their families and friends. According to Nguyen and Truong (2021), family and friends opinions play an essential role in an individual purchase intention since information gain from family and friends are considered valuable and reliable.

\section{Customers Organic Food Purchase Behaviour}

A significant part of the respondents of the study is organic food buyers (59.6\%). Consumer preferences for organic vegetable products differ depending on demographic features, educational background, occupation, age, and income (Inci et al., 2014). For this group of organic food buyers, 55\% are females, 62.9\% are aged 20-35 years old, 63.8\% are single, and $80 \%$ have an income of RM2000-RM5000 per month. In addition, the organic food buyers are familiar with organic food, with a total of $71.6 \%$ of respondents that are familiar with organic food do buy organic food. This is consistent with the previous conclusion by Adawiyah et al (2021) that consumer awareness has a considerable and beneficial impact on consumer purchase interest.

However, the frequency of buying organic food is low. It is because only $23.3 \%$ of food buyers purchase organic food several times a week. Most of the food buyers only purchase organic food a few times a year (39\%). Besides that, the generic supermarket is the prominent place for food buyers to buy organic food. $44.7 \%$ of the food buyers obtain their organic food supply from the generic supermarket. Other locations for buying organic food are health or organic speciality stores (29.3\%), online stores (12.7\%), and organic producers or organic farms (5.5\%). This study also found out that customers prefer organic vegetables and fruits. More than half of the study respondents would consume organic vegetables and fruits daily (57.3\%). In addition, $19.1 \%$ of respondents would consume organic meat and meat products daily. Among respondents, the least favourite organic food group is a baby food product, with only $5.5 \%$ of respondents consuming it daily. The demographic factors may have influenced this preference as most respondents are single with no children (67.7\%). 
Moreover, health is the primary reason organic food customers purchase organic food. The result of this study indicates that $62.8 \%$ of organic food buyers purchased organic food for health reasons. Furthermore, $17.9 \%$ of organic food customers buy organic food because of its outstanding quality. Few studies (Aygen, 2012; Gil et al., 2000; Meixner et al., 2014) confirm this conclusion; as Ali (2021) points out, customers' main reasons for purchasing organic food are health concerns. Other than that, this study found out that further reasons for buying organic food are it tastes better than conventional food (9\%), it is environmentally friendly food (8\%), and it is has a positive image and fashionable (2.5\%). Even though ecological factors are usually related to organic food customer preference (Perito et al., 2020; Irianto, 2015; Pearson et al., 2013; Ueasangkomsate \& Santiteerakul, 2016; Sangkumchaliang \& Huang, 2012); this study found out that environmental concerns were of low priority among food buyers in purchasing organic food. However, some studies in Sri Lanka (Kapuge, 2016) and Turkey (Aygen, 2012) have similar findings.

Despite the fact that the majority of food buyers who are familiar with organic food do buy organic food, $28.4 \%$ of those who are familiar do not buy the products. The most significant cause for this group of aware customers did not buy organic food is the cost, as $29 \%$ of these aware customers did not buy organic food because it is not affordable. This result contrasts with the organic food buyers' group, as $80.5 \%$ of the group are willing to pay more for organic food. Nonetheless, price sensitivity is often a significant factor for customers in not buying organic food (Higuchi \& Avadi, 2015). Additionally, the reasons for not buying organic food among aware customers are distributed pretty evenly for the rest of the items. $18.6 \%$ of aware customers did not buy organic food because there is a lack of variety in the market, $15.7 \%$ did not buy organic food because they feel no difference between organic food and conventional food, 14.6\% did not buy organic food because of the market's inability, and $13.6 \%$ did not buy organic food because organic food is not viable to them.

\section{Conclusion}

Most food buyers in Malaysia are aware of organic food. Therefore, most of them are buying organic food. However, some food buyers did not buy organic food because it is not affordable even though they are aware of organic food. Besides that, this study found out that customers often understand organic food as natural food. Additionally, they also obtain information regarding organic food from online media sources, family members, and friends. In addition, the generic supermarket is the prominent place for food buyers to obtain their organic food supplies. Organic food purchasers are also willing to pay a higher price for it. Apart from that, this study discovered that the primary motive for purchasing organic food is to improve one's health. Even though the food buyers are aware of organic food and buy organic food, the frequency of buying them is low. Therefore, further studies may investigate the low purchase frequency of organic food. Factors like price, availability in the market, and variety of products can be considered when examining organic food's purchase frequency.

\section{Acknowledgement}

A special thank you to Norfatin Amira Jasni for her collaboration in data collection and analysis.

\section{Corresponding Author}

Lily Nurainul Ashikin Ishak. Universiti Teknologi MARA Cawangan Terengganu, Kampus Dungun.

Email: lilynurainul@uitm.edu.my 


\section{References}

Aarset, B., Beckmann, S., Bigne, E., Beveridge, M., Bjorndal, T., Bunting, J., ... \& Young, J. (2004). The European consumers' understanding and perceptions of the "organic" food regime: The case of aquaculture. British Food Journal.

Adawiyah, R., Najib, M., \& Ali, M. M. (2021). Information effect on organic vegetable purchase interest through consumer preferences and awareness. The Journal of Asian Finance, Economics, and Business, 8(2), 1055-1062.

Ahmad, S. N. B., \& Juhdi, N. (2010). Organic food: A study on demographic characteristics and factors influencing purchase intentions among consumers in Klang Valley, Malaysia. International Journal of Business and Management, 5(2), 105.

Ali, B. (2021). Consumer attitudes towards healthy and organic food in the Kurdistan region of Iraq. Management Science Letters, 11(7), 2127-2134.

Aygen, F. G. (2012). Attitudes and behavior of Turkish consumers with respect to organic foods. International Journal of Business and Social Science, 18 (3), 262-273.

Baker, S., Thompson, K. E., Engelken, J., \& Huntley, K. (2004). Mapping the values driving organic food choice: Germany vs the U.K. European Journal of Marketing.

Brantsæter, A. L., Ydersbond, T. A., Hoppin, J. A., Haugen, M., \& Meltzer, H. M. (2017). Organic food in the diet: exposure and health implications. Annual review of public health, 38, 295-313.

Chan, R. Y. (2001). Determinants of Chinese consumers' green purchase behavior. Psychology \& Marketing, 18(4), 389-413.

Chinnici, G., D’Amico, M., \& Pecorino, B. (2002). A multivariate statistical analysis on the consumers of organic products. British Food Journal.

Chryssochoidis, G. (2000). Repercussions of consumer confusion for late introduced differentiated products. European Journal of Marketing.

Cicia, G., Del Giudice, T., \& Scarpa, R. (2002). Consumers' perception of quality in organic food: A random utility model under preference heterogeneity and choice correlation from rank-orderings. British Food Journal.

Connor, R., \& Douglas, L. (2001). Consumer attitudes to organic foods. Nutrition \& Food Science.

De Backer, C., Teunissen, L., Cuykx, I., Decorte, P., Pabian, S., Gerritsen, S., ... \& Corona Cooking Survey Study Group. (2020). An evaluation of the COVID-19 pandemic and perceived social distancing policies in relation to planning, selecting, and preparing healthy meals: an observational study in 38 countries worldwide. Frontiers in nutrition, 7.

Department of Statistic Malaysia. (2021). Banci Malaysia. Retrieved from https://www.mycensus.gov.my/\#latest-statistics-2020

Eyinade, G. A., Mushunje, A., \& Yusuf, S. F. G. (2021). The willingness to consume organic food: A review. Food and Agricultural Immunology, 32(1), 78-104.

Fitzpatrick, M. (2002). Food scares drive organic sales in Japan. Food Traceability Report, 2(3), 11.

Food Marketing Institute. (2001). Organic Food: Market and Marketing. Retrieved from U.S. Departmentof Agriculture: https://pubs.nal.usda.gov/sites/pubs.nal.usda.gov/files/orgmkt_0.shtml

Fotopoulos, C., \& Krystallis, A. (2002). Purchasing motives and profile of the Greek organic consumer: a countrywide survey. British Food Journal. 
Gil, J. M., Gracia, A., \& Sanchez, M. (2000). Market segmentation and willingness to pay for organic products in Spain. The International Food and Agribusiness Management Review, 3(2), 207-226.

Gore, S. (2008). What you should know about organic foods. Journal of Renal Nutrition, 18(4), e13-e15.

Higuchi, A., \& Avadi, A. (2015). Organic purchasing factors and consumer classification through their preferences in the metropolitan area of Lima, Peru. Agronomía Colombiana, 33(2), 271-279.

Hill, H., \& Lynchehaun, F. (2002). Organic milk: attitudes and consumption patterns. British Food Journal.

Huang, C. L. (1996). Consumer preferences and attitudes towards organically grown produce. European Review of Agricultural Economics, 23(3), 331-342.

Hughner, R. S., McDonagh, P., Prothero, A., Shultz, C. J., \& Stanton, J. (2007). Who are organic food consumers? A compilation and review of why people purchase organic food. Journal of Consumer Behaviour: An International Research Review, 6(2-3), 94-110.

Inci, H., Karakaya, E., \& Şengül, T. (2014). Organic Product Consumption and Customer Preferences in Urban Sections of Bingol Province. Turkish Journal of Agricultural and Natural Sciences, 1(2), 255-261.

https://dergipark.org.tr/en/pub/turkjans/issue/13305/160723

Irianto, H. (2015). Consumers' attitude and intention towards organic food purchase: An extension of theory of planned behavior in gender perspective. International Journal of Management, Economics and Social Sciences, 4(1), 17-31.

Jolly, D. A., Schutz, H. G., Diaz-Knauf, K. V., \& Johal, J. (1989). Organic foods: consumer attitudes and use. Food Technology ,43(11), 60-66.

Kapuge, K. D. L. R. (2016). Determinants of organic food buying behavior: Special reference to organic food purchase intention of Sri Lankan customers. Procedia Food Science, 6, 303308.

Makatouni, A. (2002). What motivates consumers to buy organic food in the U.K.? Results from a qualitative study. British Food Journal.

Malaysian Department of Agriculture. (2001). Portal Rasmi Jabatan Pertanian, Kementerian Pertanian dan Industri Makanan. Retrieved from Malaysian Department of Agriculture: http://www.doa.gov.my/

Meixner, O., Haas, R., Perevoshchikova, Y., \& Canavari, M. (2014). Consumer attitudes, knowledge, and behavior in the Russian market for organic food. International Journal on Food System Dynamics, 5(2), 110-120.

Meza, X. V., \& Park, H. W. (2016). Organic products in Mexico and South Korea on twitter. Journal of Business Ethics, 135(3), 587-603.

Murphy, A. J. (2008). Knowledge and consumption of organic food in New Zealand. Available at SSRN 1083856.

Narine, L. K., Ganpat, W., \& Seepersad, G. (2015). Demand for organic produce: Trinidadian consumers' willingness to pay for organic tomatoes. Journal of Agribusiness in Developing and Emerging Economies.

Nguyen, D. T., \& Truong, D. C. (2021). The Impact of Psychological and Environmental Factors on Consumers' Purchase Intention toward Organic Food: Evidence from Vietnam. Journal of Asian Finance, Economics and Business, 8(1), 915-925.

Ozguven, N. (2012). Organic foods motivations factors for consumers. Procedia-Social and Behavioral Sciences, 62, 661-665. 
Pearson, D., Henryks, J., Sultan, P., \& Anisimova, T. (2013). Organic food: Exploring purchase frequency to explain consumer behavior. Journal of Organic Systems, 8(2), 50-63.

Perito, M. A., Coderoni, S., \& Russo, C. (2020). Consumer attitudes towards local and organic food with upcycled ingredients: An italian case study for olive leaves. Foods, 9(9), 1325.

Pino, G., Peluso, A. M., \& Guido, G. (2012). Determinants of regular and occasional consumers' intentions to buy organic food. Journal of Consumer Affairs, 46(1), 157-169.

Rahman, K. M., Noor, N. A. M. (2016). In search of a model explaining organic food purchase behavior: The overlooked story of Montano and Kasprzyk's integrated behavior model. British Food Journal, 118(12).

Robinson, L., Segal, J., \& Segal, R. (2020). Organic Foods: What You Need to Know. Retrieved from Helpguide: https://www.helpguide.org/articles/healthy-eating/organic-foods.htm

Saleki, R., Quoquab, F., \& Mohammad, J. (2019). What drives Malaysian consumers' organic food purchase intention? The role of moral norm, self-identity, environmental concern and price consciousness. Journal of Agribusiness in Developing and Emerging Economies.

Sangkumchaliang, P., \& Huang, W. C. (2012). Thai Organic Food Demographics, Attitudes and Behavior. International Journal of the Computer, the Internet and Management, 20(3), 7-11.

Septianto, F., \& Kemper, J. A. (2021). The effects of age cues on preferences for organic food: The moderating role of message claim. Journal of Retailing and Consumer Services, 62, 102641.

Somasundram, C., Razali, Z., \& Santhirasegaram, V. (2016). A review on organic food production in Malaysia. Horticulturae, 2(3), 12.

Thompson, G. D., \& Kidwell, J. (1998). Explaining the choice of organic produce: cosmetic defects, prices, and consumer preferences. American Journal of Agricultural Economics, 80(2), 277-287.

Tiraieyari, N., Hamzah, A., \& Samah, B. A. (2014). Organic farming and sustainable agriculture in Malaysia: organic farmers' challenges towards adoption. Asian Social Science, 10(4), 1-7.

Ueasangkomsate, P., \& Santiteerakul, S. (2016). A study of consumers' attitudes and intention to buy organic foods for sustainability. Procedia Environmental Sciences, 34, 423-430.

Wier, M., Jensen, K. O. D., Andersen, L. M., \& Millock, K. (2008). The character of demand in mature organic food markets: Great Britain and Denmark compared. Food Policy, 33(5), 406-421.

Willer, H., Lernoud, J., \& Kilcher, L. (2016). The world of organic agriculture. Statistics and Emerging Trends, 17.

Zagata, L. (2012). Consumers' beliefs and behavioural intentions towards organic food. Evidence from the Czech Republic. Appetite, 59(1), 81-89. 